ISSN 2088-5415 (Print)

ISSN 2355-5777 (Online)

https://jurnal.ugm.ac.id/kawistara/index

https://doi.org/ 10.22146/kawistara.49816

JURNAL KAWISTARA

VOLUME 10

No. 3, 22 Desember- 2020

Halaman 265-281

\title{
JOGJA DANCE COMMUNITY \\ RUANG NEGOSIASI DALAM JAGAD TARI \\ DI YOGYAKARTA
}

\author{
JOGJA DANCE COMMUNITY \\ THE NEGOTIATION SPACE IN THE SCENE OF DANCE IN YOGYAKARTA
}

\author{
${ }^{* 1} R r$. Paramitha Dyah Fitriasari dan Galih Prakasiwi ${ }^{2}$ \\ Program Studi Pengkajian Seni Pertunjukan dan Seni Rupa \\ Sekolah Pascasarjana Universitas Gadjah Mada
}

Submitted: 19-09-2019; Revised: 17-07-2020; Accepted:07-12-2020

\begin{abstract}
Yogyakarta has a strong identity with the preservation of traditional arts based on the dominant power of Yogyakarta Palace as its center. The rules of traditional arts that bind, create opportunities for development and new innovations based on freedom. This paper looks at the realization of freedom and strategy in positioning themselves in the dance universe in Yogyakarta. Data collection is carried out through literature study and interviews. The data is represented by observations in 2016 to 2018. Jogja Dance Community is a network that houses dance groups in Yogyakarta. Some groups are joined by young people in the embodiment of freedom through its contemporary. This choice requires a strategy to be able to negotiate with the dance universe in its place.
\end{abstract}

Keywords: Dance group; Contemporary; Negotiation; Yogyakarta; Young people.

\begin{abstract}
ABSTRAK
Kesenian Yogyakarta memiliki identitas yang kuat dengan upaya preservasi seni tradisi berbasis kuasa dominan Kraton Yogyakarta sebagai sentralnya. Aturan seni tradisi yang mengikat, memunculkan peluang pengembangan maupun inovasi baru berdasar kebebasan. Tulisan ini melihat perwujudan kebebasan dan strategi dalam memposisikan diri pada jagad tari di Yogyakarta. Pengambilan data dilakukan melalui studi pustaka dan wawancara. Data tersebut dikelindankan dengan pengamatan pada 2016 hingga 2018. Jogja Dance Community merupakan jaringan yang menaungi kelompokkelompok tari di Yogyakarta. Beberapa kelompok yang tergabung diiniasiasi oleh anak-anak muda dalam pengejawantahan kebebasan melalui kekontemporerannya. Pilihan tersebut memerlukan strategi untuk dapat bernegosiasi dengan jagad tari di tempatnya bernaung.
\end{abstract}

Kata Kunci: Kelompok Tari; Kontemporer; Perundingan; Yogyakarta; Anak Muda.

${ }^{*}$ Corresponding author: paramitha_df@ugm.ac.id

Copyright@ 2020 THE AUTHOR (S). This article is distributed under a Creative Commons Attribution-Share Alike 4.0 International license. Jurnal Kawistara is published by the Graduate School of Universitas Gadjah Mada. 


\section{PENGANTAR}

Yogyakarta selama ini dikenal sebagai kota yang kental dengan jagad tradisi, mulai dari kesenian, tata krama, hingga upacara adat. Keberadaan Kraton dan kebudayaan yang melingkupinya telah menjadi citra Yogyakarta yang didukung oleh jargon pemerintah maupun pemberitaan media masa. Kesenian klasik merujuk pada bentuk kesenian yang tumbuh dan dimiliki Kraton Yogyakarta sebagai bagian dari seremonial, ritual, serta hiburan. Kesenian rakyat yang tersebar di kabupaten sekitarnya pun turut menjadi perbincangan (Kayam, 2000). Meskipun terkadang dioposisikan dalam bingkai klasik dan kerakyatan, keduanya lalu digolongkan ke dalam perbincangan seni tradisi.

Krida Beksa Wirama (KBW) merupakan agen pertama yang membawa tari klasik dapat dipelajari oleh masyarakat luas. Awalnya taritari klasik hanya dapat digelar di lingkungan istana, tetapi Pangeran Tejakusuma berinisiatif membawanya ke luar Kraton dengan mendirikan KBW pada 1918 atas seizin Sri Sultan Hamengku Buwana VII. Hal tersebut dilakukan sebab pergolakan politik internal keluarga kerajaan yang terjadi berdampak pada pelembagaan kesenian istana terhenti (Hadi, 2001:30). KBW menjadi organisasi yang membantu guru-guru tari dari Kraton dan beban finansial lainnya. Kemudian beberapa grup tari lain yang diinisiasi oleh orang-orang berdarah biru pun mengikuti kemunculannya seperti Paguyuban Surya Kencana, Yayasan Pamulangan Beksa Sasmita Mardawa, Siswa Among Beksa. Kelompok tersebut mengadakan latihan dan pembelajaran terbuka bagi siapa saja yang ingin mempelajari tari klasik gaya Yogyakarta. Produksi karya tari baru yang berpijak dari berbagai aturan tari klasik pun muncul dari masing-masing kelompok. Pelembagaan tari selanjutnya diperkaya oleh instutisi pendidikan formal yakni Sekolah Menengah Karawitan Indonesia - SMKI (sekarang SMKN 2 Kasihan) dan Institut Seni Indonesia (ISI) Yogyakarta.

Berbeda halnya dengan tari kerakyatan yang tumbuhnya dianalogikan dengan ungkapan adoh ratu cedhak watu (Jauh dari ratu, dekat dengan batu). Tari kerakyatan tumbuh di daerah pertanian, pesisir pantai, atau pegunungan yang jaraknya jauh dari Kraton. Jarak ini berpengaruh pada transmisi dan variasi bentuk tariannya. Istilah tari kerakyatan cenderung dioposisikan dengan tari klasik. Apabila tari klasik merujuk pada tarian gaya Kraton Yogyakarta, maka tari kerakyatan merupakan tarian yang muncul dan tumbuh di luar tembok istana. Jathilan, angguk, montro, badui, srandul adalah beberapa contoh yang sering diberi label sebagai seni kerakyatan. Beberapa kelompok kesenian hadir di tengah-tengah masyarakat dengan beragam model, ada yang muncul atas inisiatif pelaku seni, ada pula yang dibina oleh akademisi. Baik tari klasik maupun kerakyatan, keduanya digolongkan dalam bingkai seni tradisi.

Dewasa ini, dana keistimewaan hadir meneropong potensi kesenian di kantongkantong desa budaya maupun rintisan desa budaya. Sasaran yang difasilitasi tentu kesenian unggulan masing-masing daerah, merujuk pada tari klasik dan kerakyatan. Bagaimana dengan tari kontemporer? Agaknya pemerintah jarang mengirimkan delegasi misi kesenian atau muhibah seni dengan genre tari kontemporer. Chilvers dan Glaves-Smith mendefinisikan seni kontemporer sebagai sebuah karya dengan spirit waktu (of its time), kemudian bergeser pada siapa yang memaknai dan menemukan dalam praktiknya (2009:434).

Tari kontemporer bagi awam bahkan beberapa seniman sekalipun sering dilawankan dengan tari tradisi. Bila tari tradisi memiliki pakem tertentu dan dianggap sebagai warisan dari nenek moyang, maka kontemporer dianggap sebagai tari baru atau kekinian tanpa aturan gerak yang mengikat. Alasan itulah yang mungkin menjadikan kelompok seni kontemporer berdiri secara independen tanpa dukungan pemerintah secara langsung. Pemerintah lebih memilih pendampingan dan fasilitasi pada kelompok yang dianggap sebagai kelompok seni tradisi.

Padaawal perkembangantarikontemporer di Amerika, Jowitt dalam pengantar buku Fifty Contemporary Choreographers mengungkapkan tari kontemporer merujuk pada spirit 
perlawanan individual koreografer (1999:4). Perkembangan tari di Asia, bagi Chattarjea mengalami mistranslasi akibat rujukannya pada estetika Eropa dan Amerika. Padahal Asia memiliki seni dan budaya tradisional yang tumbuh di tengah masyarakatnya, seharusnya hal ini dapat memengaruhi estetika kontemporer Asia (Chattarjea, 2013). Indonesia mengenal istilah tari kontemporer seiring berdirinya Pusat Kesenian Jakarta di Taman Ismail Marzuki Jakarta pada tahun 1968 ((2017:83). Keterbukaan pada berbagai jenis tarian belum terbentuk dengan sehat karena ekosistem seni tarinya tidak berkembang dengan optimal.

Michael HB Raditya dalam makalahnya yang berjudul Mencermati Kontemporer dan Memahami Seni-nya mengutarakan bahwa ketika masyarakat menyaksikan pertunjukan kontemporer, maka asumsinya adalah kesenian yang 'baru', 'aneh', bahkan 'nyleneh'. Sebagaimana tari hadir menjawab zaman. Jagad tari pun bergulir, awalnya kesenian barangan yang berkeliling dari pintu rumah satu ke pintu yang lain (Raditya, 2015). Lalu repertoar tari yang juga merupakan batangan (tebakan) antara penari dan pengendangnya, tidak memiliki urutan gerak yang baku. Lalu tarian itu beberapa diserap menjadi inspirasi karya tari dengan stilisasi dan distorsi hingga terbentuk konsensus pakem-pakem gerak tertentu dengan urutan gerak yang pasti. Hadir setelahnya tari kontemporer melawan pendisiplinan itu. Tari kontemporer Indonesia biasanya lewat dengan bekal kosa gerak etnis dari koreografer terbawa dalam koreografinya, meski ada pula yang mencoba mencari 'tradisi' tubuhnya sendiri. Pencapaian kosa gerak pribadi itu diperlukan pengalaman ketubuhan yang beragam, cerapan dari berbagai genre atau gaya tari. Hal tersebut senada dengan ungkapan Ray Leeper seorang direktur NUVO Dance Convention serta koreografer So You Think You Can Dance asal Los Angeles mengenai tari kontemporer:

"Contemporary is anything current. It's more of a style, but rooted in technique, because it's a fusion of several techniques-ballet, jazz, modern. But I wouldn't want to be labeled a strictly contemporary jazz choreographer. I'm inspired by music or a concept I want to have realized through movement. If people really knew where contemporary came from, we wouldn't be so quick to label it contemporary, when it might be contemporary jazz or contemporary ballet."

(http:/ / www.dancemagazine.com / modern_vs_contemporary-2306900829.html diakses pada Minggu, 23 April 2017 pukul 11.32)

Berdasarkan pernyataan tersebut, bila karya tari itu berpijak dari tradisi maka dapat dinyatakan ke dalam contemporary tradition. Inilah yang marak ditemui pada beberapa koreografer muda yang mencoba menyusun karya tari kontemporer. Seperti yang tampak pada acara Jogja Imaginary Performing Art (JIPA) di penghujung 2016 lalu. Empat orang koreografer muda unjuk diri dalam acara itu, pilihannya adalah pementasan hasil akhir atau melaporkan kerja studio yang tengah dikerjakan. Bagus Bang Sada, Pulung Jati Rangga, Galih Puspita Karti, dan Citra Pratiwi memunculkan idiom etnis masing-masing dalam showcase sore itu.

Jogja Imaginary Performing Art diinisiasi oleh Bambang Paningron, Direktur Asia Tri dan Jogja International Street Performance (JISP). Bermula dari kegelisahannya mengenai pergerakan tari kontemporer Indonesia. Regenerasi penari kontemporer yang mengupayakan kualitas tarinya dinilai tipis. Beberapa kelompok tari dalam kurun lima tahun terakhir bermunculan di Yogyakarta dan diinisiasi oleh anak-anak muda di bawah 30 tahun (beberapa di antaranya fresh-graduated kala itu). Kelompok-kelompok tersebut menyuguhkan tari kontemporer sebagai salah satu menunya. Beberapa hanya menempa anggota berproses bak sebuah laboratorium dan menerima 'pesanan' karya tari, beberapa yang lain juga membuka sanggar tari dengan kegiatan belajar mengajar. Paningron menilai pergerakan kelompok-kelompok ini tentu tidak mulus, namun mengalami pula jalanan yang terjal dan berliku. Masalah demi masalah tentu dihadapi oleh masing-masing kelompok ketika berproses maupun berkarya, tetapi dinilai tidak ada komunikasi antarkelompok. Banyak kemungkinan masalah yang dihadapi 
juga serupa atau sudah pernah dialami oleh kelompok lain. Komunikasi tersebut menjadi penting untuk membangun hubungan dialektis, mendiskusikan apa yang dialami bersama dan berbagi informasi.

Ayu Permata Dance Company (APDC), Galih Puspita Karti, Sanggar Seni Kinanti Sekar, Mini Festival Tari Paradance, Kawung Art Culture, Mila Art Dance dikumpulkan oleh Paningron untuk diajak berdiskusi merealisasikan ide. Gayung bersambut, beberapa kelompok dan komunitas tari itu pun menjadi organisator bersama dalam acara Jogja Imaginary Performing Art. Terhitung selama dua hari 27 dan 28 Desember 2016 sekitar 25 insan seni muda hadir. Acara ini merupakan ajang pertemuan insan-insan tari khususnya bagi koreografer dan penari muda, berinteraksi satu sama lain, mendiskusikan permasalahan dan keresahan yang ada. Pertemuan kali ini tidak ada narasumber yang duduk di depan, audience lah yang akan saling bertanya dan menjawab. Format yang dilakukan sengaja diperuntukkan bagi anak muda untuk juga dapat berdiskusi dan menyampaikan idenya, Paningron menambahkan bila senior hadir dikhawatirkan akan membuat anak-anak muda ini takut bersuara atau mengiyakan patron yang dibuat. Paningron pun menjelaskan posisi dirinya bahwa ia akan hadir sebagai pendengar, membuka, dan menutup acara saja. Dalam dua hari terdapat dua termin acara yang pertama adalah menonton video lalu berdiskusi, lalu termin kedua melihat showcase secara langsung lalu mendiskusikannya juga. Beberapa koreografer dan penaripenari antusias mendaftarkan diri. Ketika pelaksanaan terjadi, acara yang dipandu oleh Nia Agustina sebagai moderator ini rupanya belum mendapatkan banyak respon aktif dari audience hanya beberapa saja yang angkat bicara.

Berawal dari JIPA kemudian terbentuk Jogja Dance Community yang terbuka bagi kelompok maupun koreografer mana pun untuk berdiskusi maupun bertukar informasi. Dari fenomena yang sudah dipaparkan sebelumnya, rumusan masalah yang muncul dalam tulisan ini adalah bagaimana posisi Jogja Dance Community dalam jagad tari Yogyakarta dan strategi mereka dalam mengembangkan tari kontemporer di Yogyakarta?

Penelitian ini dilakukan di Yogyakarta. Fokus penelitian adalah Jogja Dance Community. Di dalam komunitas tersebut terdapat beberapa sanggar atau grup tari Ayu Permata Dance Company (APDC), Galih Puspita Karti, Sanggar Seni Kinanti Sekar, Mini Festival Tari Paradance, Kawung Art Culture, Mila Art Dance. Penelitian ini menggunakan pendekatan kualitatif, dan salah satu kunci keberhasilan penelitian kualitatif adalah ketepatan dalam memilih informan. Informan inti dari penelitian ini adalah Pencetus Jogja Dance Community yaitu Bambang Paningron. Anggota Jogja Dance Community yaitu Ayu Permata Dance Company (APDC), Galih Puspita Karti, Sanggar Seni Kinanti Sekar, Mini Festival Tari Paradance, Kawung Art Culture, Mila Art Dance. Teknik pengumpulan data dalam penelitian ini dilakukan dengan pendekatan kualitatif. Pengumpulan data melalui kepustakaan merupakan studi awal untuk mendapatkan informasi tertulis dari beberapa referensi artikel, buku, majalah, jurnal, dan makalah yang berhubungan langsung maupun tidak langsung dengan tema penelitian. Disertasi Eko Supriyanto (2015) berjudul "Perkembangan Gagasan dan Perubahan Bentuk serta Kreativitas Tari Kontemporer Indonesia (Periode 1990-2008)". Dalam pembahasannya, Eko mengambil studi kasus lima koreografer Indonesia yaitu Martinus Miroto, Mugiyono Kasido, Hartati, Jecko Siompo, dan Eko Supriyanto. Eko menjelasakan kecenderungan koreografer kontemporer Indonesia yang menjadikan tradisi sebagai dasar kreativitas. Disertasi Sal Murgiyanto (1991) yang berjudul Moving Between Unity and Diversity: Four Indonesian Choreographers. Disertasi ini menjadi penting untuk melacak awal perkembangan tari kontemporer di Indonesia. Sal mengambil studi kasus terhadap empat seniman tari kontemporer yaitu Bagong Kussudiardja, Retno Maruti, Sardono W Kusumo, dan Huriah Adam. Dalam pembahasannya diungkap amsing-masing koreografer mulai dari kehidupannya sampai perjalanan kreatif dan inovasi yang dilakukan. Kedua disertasi 
tersebut berkontribusi dalam melihat kasus kooregrafer Indonesia terdahulu, penelitian mengenai koreografer muda periode 2015-2017 di Yogyakarta belum dibahas. Berdasarkan studi pustaka di atas, dapat disimpulkan bahwa belum ada yang menulis mengenai pelestarian dan pemberdayaan bidang seni budaya dari sisi inovasi dalam mendukung keistimewaan Jogja. Oleh sebab itu, dapat dikatakan penelitian ini masih orisinil.

Negosiasi didefinisikan sebagai proses interaksi transaksional seorang individu yang mengalami situasi interkultural (Ting-Toomey, 1999:40). Situasi ini tidak hanya berkenaan dengan wilayah teritorial secara geografis, akan tetapi berkaitan pula dengan kultur yang menubuh di dalam diri. Penelitian menawarkan sudut pandang dari seorang pengkarya (dalam hal ini koreografer maupun kelompok yang tergabung dalam JDC) melakukan negosiasi melalui kerja kreatif. Kreativitas yang diasah dan disadari menjadi ruang negosiasi guna meletakkan posisi diri di tengah kultur dominan.

Demi memperoleh hasil penelitian yang lebih baik dan lengkap maka dilakukan beberapa teknik pengumpulan data seperti observasi, wawancara mendalam, wawancara bebas, peta dan dokumen (Spradley, 1975:5). Participant Observation dilakukan untuk mendatangi dan melihat secara langsung proses berkesenian dari sanggar tari yang ada, aksi pentas dan latihan reguler yang dilakukan oleh masing-masing kelompok. Di samping itu, observasi juga dilakukan dengan bergaul dengan lingkungan informan, mendengarkan komentar, dan argumen-argumen informan dengan berusaha untuk tidak memberikan pengaruh apapun kepada mereka ketika mereka menyampaikan pendapat.

\section{PEMBAHASAN}

\section{Festival dan Komunitas Tari di Yogyakarta}

Aktualisasi diri seorang seniman membutuhkan ruang. Ruang dalam hal ini merujuk pada kegiatan, acara, maupun sekelompok orang yang mengakomodir proses maupun produk kreatif pelaku seni. Dunia seni membutuhkan aktivitas kooperasi yang terdiri dari beberapa peran (Becker, 2008:35). Sal Murgiyanto mengungkapkan bahwa terdapat empat pilar yang menyangga tumbuh kembang kemajuan tari yakni pelaku, penonton, kritikus, dan penyelenggara (Supriyanto, 2018:14). Pelaku adalah koreografer (pencipta) dan penari (penyaji) yang mempresentasikan karya. Kondisi pelaku mempengaruhi keberhasilan dan kualitas karya. Tingkat apresiasi penonton juga menjadi bagian dari pendukung perkembangan tari. Kritikus ialah seorang penonton ahli di antara penonton yang menyaksikan pertunjukan. Keberadaan kritikus mampu menaikkan kualitas tari sebab seorang kritikus mampu menerjemahkan dan memberi komentar atas karya. Penyelenggara merupakan panitia, inisiator, atau produser acara festival, lokakarya, kegiatan dan sebagainya. Penyelenggara ialah penyedia ruang temu pelaku, penonton, kritikus, bahkan penyelenggara lain. Ruang bukan merujuk pada bangunan, melainkan ruang temu yang di dalamnya terdapat relasi sosial antarpelakunya.

\section{Jogja Arts Festival}

Jogja Arts Festival merupakan nama yang diberikan untuk asosiasi acara yang diproduksi oleh Jaran Production seperti Asia Tri Jogja dan Jogja International Street Performance. Festival ini dimotori secara umum oleh Bambang Paningron, menjadi acara tahunan yang ditunggu oleh masyarakat tari untuk bisa tampil dalam perhelatan ini. Perjalanannya tentu panjang dan beragam, masing-masing mata acara pun memilki cerita tersendiri. Bermula dari Paningron yang menangani Festival Kesenian Yogyakarta (FKY) di tahun 2003 dan 2004. Acara yang biasanya berupa pawai grup-grup kesenian Yogyakarta lantas dimunculkan panggung utama. Penampil dalam FKY 2003 itu antara lain Boi G. Sakti, Martinus Miroto, dan Eko Supriyanto. Paningron melihat kala itu pertunjukan tari klasik Yogyakarta sangat dominan, munculnya karya tari garapan baru selalu berbasis dari tari klasik atau tradisi yang kuat. Miroto dan Eko baru kembali dari Amerika saat 
diundang untuk tampil dalam acara ini. Saat itu Paningron mulai merasa bahwa seniman (khususnya Yogyakarta) membutuhkan ruang untuk berkarya, menampilkan proses dan latihan yang telah ditempa. Bila tari klasik telah diakomodir oleh Keraton dan sanggar-sanggar tari klasik yang lain maka bagaimana dengan tari kontemporer.

Tahun 2010 Jogja International Street Performance (JISP) dihelat di sepanjang jalan Malioboro. Pada perkembangannya, kini JISP merambah ke jalan Mangkubumi. Tujuan awal diadakannya festival ini menurut Paningron adalah upaya untuk mengkritisi pemerintah atas ketersediaan ruang dan kesempatan berpentas yang kurang dalam hal kuantitas dan kualitas. Bagi seniman dan masyarakat ruang alternatif ini menjadi pemicu untuk berimajinasi serta melahirkan karya kreatif, stigma bahwa pertunjukkan hanya bisa dihelat di gedung dengan ukuran dan kenyamanan tertentu dialihkan dengan tawaran lain. Malioboro sebagai pusat kota dipilih sebagai tempat pertemuan hangat seniman dan penonton dalam festival ini. Pemanfaatan kawasan Malioboro dalam seni pertunjukan sebelumnya sebagai rute karnaval, namun JISP membuat beberapa area pentas serta panggung kecil untuk seniman yang berpartisipasi. Sejauh ini, seniman yang tampil ini memiliki beragam bentuk karya seni. Beberapa mencoba berbaur dengan penonton, namun beberapa yang lain seperti layaknya penampilan di atas panggung konvensional. JISP 2017 baru saja dihelat 24-25 September 2017 lalu dengan jargon the dancing city yang dipertebal tahun ini sebab kerjasama dengan dance cities network yang telah berjalan di Eropa mulai dibangun. Meskipun berawal dari ide untuk mengkritisi kurangnya ruang, JISP mendapat dukungan Dinas Pariwisata Provinsi Daerah Istimewa Yogyakarta.

Tahun 2009 Paningron dipanggil oleh Joko Widodo yang saat itu menjabat sebagai walikota Solo untuk merumuskan ide membuat acara tari. Pasca berdiskusi bersama tim yang dipanggil terbentuklah SIPA (Solo International Performing Arts). Untuk itu, mengimbangi \& alasan sinergisme, Jogja Art Festival yang telah dimulai pada 2004 berganti nama menjadi JIPA
(Jogja International Performing Arts) Festival pada tahun 2010. Pertunjukan yang dipentaskan oleh JIPA tidak hanya tari, tetapi juga musik dan teater. JIPA 2014 hadir dengan format dan program yang beragam tampak ada kemiripan dengan Indonesian Dance Festival, yaitu main performance, showcase, workshop, master class, dan coaching clinic.

Asia Tri, JISP, dan JIPA hadir sebagai ruang yang mengakomodir tari kontemporer untuk berpentas. Menurut Paningron, pihaknya tidak melakukan pembatasan atas genre tertentu saja yang masuk dalam festival-festival ini. Awal penyelenggaraan panitia memang mengundang seniman yang tampil, namun pada 2012 mulai banyak pihak yang menghubungi untuk mendaftar. Hingga kini pendaftar memang lebih banyak seniman dan kelompok tari kontemporer, kurasi terhadap karya pun tidak ketat sebab memang diharapkan ruang ini terbuka bagi kelompok atau koreografer baik nasional maupun internasional. Mulai tahun 2015, Paningron tampak mengelompokkan festivalfestival yang diinisiasi olehnya dalam satu payung asosiasi dan diberi nama Jogja Arts Festival. Beberapa festival ini menjadi pemicu munculnya kelompok tari yang diinisiasi oleh anak muda (di bawah 30 tahun) mengarah ke ranah kontemporer.

Tahun 2016 keadaan tidak sesuai dengan rencana yang disusun, sebab dana dari pemerintah yang seharusnya direncanakan didapatkan oleh JIPA dibatalkan. Kegelisahan ini lalu menumbuhkan keinginan mengalihkan JIPA dalam format yang lain. Berdasarkan pengalamannya dalam melihat berbagai tari di banyak tempat serta repertoar yang dilihat di festival bentukannya selama ini, Paningron kemudian memiliki inisiatif untuk mengumpulkan beberapa kelompok anak muda yang tumbuh dan sedang dalam proses ke arah pertunjukan kontemporer. Beberapa hanya menempa anggota berproses bak sebuah laboratorium dan menerima 'pesanan' karya tari, beberapa yang lain juga membuka sanggar tari dengan kegiatan belajar mengajar. Paningron menilai pergerakan kelompok-kelompok ini tentu tidak mulus, 
tetapi mengalami pula jalanan yang terjal dan berliku. Masalah demi masalah tentu dihadapi oleh masing-masing kelompok ketika berproses maupun berkarya, akan tetapi dinilai tidak ada komunikasi antarkelompok. Banyak kemungkinan masalah yang dihadapi juga serupa atau sudah pernah dialami oleh kelompok lain. Komunikasi tersebut menjadi penting untuk membangun relasi, mendiskusikan apa yang dialami bersama dan berbagi informasi.

Ayu Permata Dance Company (APDC), Galih Puspita Karti, Sanggar Seni Kinanti Sekar, Mini Festival Tari Paradance, Kawung Art Culture, Mila Art Dance dikumpulkan oleh Paningron untuk diajak berdiskusi merealisasikan idenya. Gayung bersambut, beberapa kelompok dan komunitas tari itu pun menjadi organisator bersama dalam acara pertama Jogja Imaginary Performing Art (JIPA). Terhitung selama dua hari 27 dan 28 Desember 2016 sekitar 25 insan seni muda hadir. Acara ini merupakan ajang pertemuan insan-insan tari khususnya bagi koreografer dan penari muda, berinteraksi satu sama lain, mendiskusikan permasalahan dan keresahan yang ada. Pertemuan kali ini tidak ada narasumber yang duduk di depan, audience lah yang akan saling bertanya dan menjawab. Format yang dilakukan sengaja diperuntukkan bagi anak muda untuk juga dapat berdiskusi dan menyampaikan idenya, Paningron menambahkan bila senior hadir dikhawatirkan akan membuat anak-anak muda ini takut bersuara atau mengiyakan patron yang dibuat. Paningron pun menjelaskan posisi dirinya bahwa ia akan hadir sebagai pendengar, membuka, dan menutup acara saja.

Pertemuan bersama dari berbagai kelompok ini menumbuhkan jaringan yang perlu dibangun untuk saling berinteraksi dan belajar satu sama lain. Berawal dari JIPA kemudian terbentuk Jogja Dance Community yang terbuka bagi kelompok maupun koreografer mana pun untuk berdiskusi maupun bertukar informasi.

Jogja Dance Community (JDC) diharapkan menjadi payung besar bagi kelompok tari maupun koreografer independen. Selama ini komunikasi antarkomunitas dan kelompok dirasa kurang terbangun. Acara dan kegiatan yang dilakukan oleh kelompok maupun perorangan lebih banyak dikelola sendiri tanpa bersinggungan dengan yang lain. Kelompok-kelompok ini muncul atas alasan yang beragam. Ruang-ruang alternatif pun kian banyak diminati dalam kerja eksploratif. Masing-masing kelompok membangun arena guna mengakomodir proses kekaryaan mereka dan ajang pertemuannya dengan publik. Hal ini terbaca oleh Paningron, JDC dihimpun demi terciptanya ruang interaksi antarseniman serta orang-orang yang bekerja disekitarnya. Sebagaimana Sal Murgiyanto mengatakan bahwa pertunjukan akan tumbuh dengan sehat apabila empat pilar penyangganya dapat terbina, yakni pelaku (seniman), penonton, kritik, dan penyelenggara. Pergerakan kelompok-kelompok kecil yang mulai bermunculan ini bagi Paningron perlu dibaca arahnya secara strategis. Payung besar inilah yang ditawarkan sebagai penghimpun keseluruhan dan membawa ruang kecil-kecil ini ke ruang selanjutnya. Melalui JDC diharapkan terjadi diskusi, interaksi, dan arena kontestasi sehingga akan memicu perkembangan tari kontemporer di Yogyakarta secara utuh.

\section{Paradance: Festival mini seni gerak dan tari}

Bermula dari pengalaman Nia Agustina (28 tahun) yang ingin menampilkan karya tari di masa senggangnya usai lulus dari sekolah pascasarjana jurusan pendidikan matematika. Nia yang memiliki pengalaman belajar tari di sanggar Didik Nini Thowok, Pujokusuman, dan Suryokencana ingin tampil dengan karya koreografinya sendiri. Sebagai seseorang yang bergelut di sanggar dan belum banyak memiliki pengalaman menampilkan karya tarinya sendiri ke area publik, Nia kemudian mengajak Ayu Permata Sari, Putri, dan Mila Rosinta untuk tampil bersama membawakan karya tari masing di Balai Budaya Samirono. Acara yang dihelat pada tahun 2014 ini tercetus pertama kali dengan nama Paradance. Urusan teknis dan pendanaan diambil dari saku Nia dan Ahmad Jalidu. 
Seusai acara Paradance pertama, respon baik terdengar dari beberapa kalangan penari. Mulai saat itu Nia menyadari ruang pentas masih kurang secara kuantitas. Ia seolah berkaca dari pengalaman pribadinya, Paradance dihelat sebagai area untuk ajang tampilnya koreografer muda dari semua kalangan baik yang berlatar belakang tari maupun yang tidak. Paradance ingin mengakomodir siapapun yang ingin tampil dengan jenis tarian apapun. Ibarat sebelum menjadi koreografer profesional, tahap yang dilalui adalah amatir dulu. Ruang untuk menampilkan karya yang masih amatir ini lah yang coba ditangkap oleh Paradance sebagai peluang.

Paradance pertama hingga keenam belas berbagai penampilan telah mewarnai panggungnya, dari berbagai usia, dari pertunjukan angguk, hiburan, hingga kontemporer. Setiap kali penyelenggaraan ada 6 hingga 7 penampil dengan jumlah peminat semakin banyak. Kini penyebaran melalui sosial media memungkinkan untuk menutup pendaftaran bila telah memenuhi kebutuhan. Tampak pula pada Paradance ke-16 dihelat pada 27 Agustus 2017 di Balai Budaya Minomartani: Arbinur (Bandung), Bravery Dancer (Yogyakarta), Magnum Arkan (Sukoharjo), Novianti (Jakarta), Syah Fitri Ken (Sragen), Tri Putra Mahardika (Jambi), Tutu Club USD (Yogyakarta), Wisnu Dermawan (Temanggung), Yande Oplonk \& Yoga Aditya (Bali). Paradance yang didukung oleh Balai Budaya Minomartani untuk menyediakan tempat pentas, lampu panggung, pengeras suara (sound system), dan konsumsi. Penampil tidak mendapatkan subsidi apapun dalam bentuk uang, tetapi respon publik rupanya positif menyambut ruang alternatif ini. Hal ini pun menunjukkan bahwa beberapa koreografer dan penari muda membutuhkan ruang untuk menampilkan karyanya.

\section{Kinanti Sekar Rahina (Sanggar Seni Kinanti Sekar)}

Sekar Kinanti Rahina (29 tahun) memulai menari sejak TK. Saat itu, bergerak mengikuti irama musik dan lagu baginya adalah menari. Hingga pada suatu ketika, ada seorang mahasiswa ISI Yogyakarta mengajaknya untuk tampil pada acara peringatan kemerdekaan di kampungnya. Dari situlah ia mengenal pentas menari. Sekar Kinanti kecil, mulai sadar akan kesenangannya dilihat dan tampil dihadapan banyak orang. Menurutnya menari membuatnya percaya diri. Peristiwa itu yang mendorongnya untuk belajar menari. Tidak lama kemudian Ia ikut bergabung di Sanggar tari Pujo kusuman untuk belajar tari klasik. setelah beberapa waktu belajar tari klasik, sekar menyaksikan karya tari. Di sana keinginannya untuk menari semakin kuat. Ayahnya mulai mengenalkan Sekar dengan tari kreasi melalui Didik Ninik Towok. Saat itu ia belajar tari kreasi untuk anak, tetapi sayangnya Sekar merasa tidak sreg dengan jenis tari kreasi tersebut. Menyatakan ketidaknyamanannya itu, Sekar mulai belajar tari balet kelas 3SD di Hotel Dirict. Yang diajar oleh Bu Helvi. Sekar merasa senang dan menemukan tempat belajar menari yang ia senangi. Akan tetapi, masa belajar baletnya harus terhenti di kelas 6 SD. Dia lupa alasannya apa, yang Sekar ingat karena gurunya berhenti, dan ia harus melanjutkan masuk SMP.

Masa SMP, Sekar mengikuti ekstrakurikuler tari Yogyakarta. Sekali lagi ia merasa tidak suka dengan gerakan tari jawa yang memiliki tempo lambat. Meskipun berhenti les balet, ia tidak berhenti begitu saja. Sekar mengakomodir kesukaannya dengan cara mengisi acara-acara di sekolah bersama teman-temannya. Tarian yang Ia ciptakan lebih mengarah ke dance lagu seperti yang ia lakukan di masa TK. Meskipun belum tahu yang dilakukan adalah improvisasi, sekar baru menyadari bahwa merespon musik dengan merasakan tubuh sehingga dapat menciptakan gerakan, baginya adalah bagian improvisasi yang ia pelajari secara otodidak.

Setelah lulus SMP, Sekar memilih untuk melanjutkan di SMKI Yogyakarta dengan mengambil jurusan tari. Tercatat sebagai siswi SMKI, Sekar mulai paham tentang apa yang telah ia lakukan selama ini. Ia mampu mendefinisikan secara konkret bahwa apa yang ia lakukan adalah bagian dari improvisasi. Lulus dari SMKI Yogyakarta, ia memilih untuk meneruskan bakatnya dan menempuh pendidikan di Institut Seni Indonesia 
Yogyakarta. Saat masuk kuliah ia semakin banyak mendapat pemahaman tentang tari. Terutama tentang tari jawa yang tidak pernah ia sukai.

Tahun 2009 Sekar bergabung dalam Tembi Dance Company (TDC) yang diinisiasi pula oleh Bambang Paningron di Rumah Budaya Tembi, bersama Mila Rosinta dan Made Dyah Agustina. Sederet pengalaman berproses, berlatih, dan berpentas ia dapatkan di sini, baik pementasan dalam negeri maupun partisipasi pada Asia Tri. Seusai TDC dinyatakan bubar, Sekar kemudian memupuk kemungkinan ruang mandiri sebagai tempat berproses dan berbagi. Akhirnya pada 2015 Sanggar Seni Kinanti Sekar (SSKS) berhasil didirikan di Kelas Pagi Yogyakarta dalam manajerial yang dikomandoi Bagas Arga. Kegiatan sanggar dimulai awal bulan Agustus, pada perencanaan secara tertulis sanggar ini menekankan pada ihwal kebebasan berekspresi dan bersahabat dengan alam. Siswa diharapkan dapat berpartisipasi dalam proses belajar dan dekat dengan lingkungan sekitar. SSKS memiliki berbagai program pembelajaran yakni tari, tembang dan baca tulis Aksara Jawa. Penanggung jawab dan fasilitator kelas berasal dari seniman otodidak dan beberapa lulusan sekolah seni.

\section{Mila Rosinta (Mila Art Dance)}

Nama Mila Rosinta (29 tahun) mulai dikenal sejak kiprahnya di Tembi Dance Company bersama Sekar dan Made Dyah. Mila mulai belajar menari sejak kecil dengan ketertarikan belajar tari Bali di Jakarta. Kehidupan di kota metropolitan ia jalani hingga bangku SMP. Berbagai kursus ia jalani di Jakarta, tetapi menari merupakan kegiatan yang selalu ia jalani dengan intens. Mulai pendidikan SMA, Mila pindah ke Yogyakarta dan melanjutkan pendidikan seninya di ISI Yogyakarta. Bergabung dalam TDC mengajarkan teknik menari, mengorganisir acara, hingga bekal untuk membuat kelompok (dance company) sendiri. Bubarnya TDC makin memperkuat bahwa masing-masing penarinya mendirikan arena berkarya sendiri dalam hal ini semacam sanggar.
Bekal pengalaman hidup di Jakarta dan ibunya yang bekerja di bidang perfilman membuatnya meneropong peluang pemanfaatan di Yogyakarta. Ia membuat komunitas tari perempuan tahun 2012 dengan nama Mila Art Dance (MAD). Komunitas ini dibuat sebagai tempat untuk berproses hingga berkarya secara terbuka. Kegiatan tersebut meliputi: berlatih, pementasan karya, dan workshop. Pada perkembangan selanjutnya, MAD membentuk sekolah tari yang diberi nama Mila Art Dance School (MADS) pada 2015. Kelas yang dibuka cukup beragam, yaitu repertoar tari Yogyakarta, Sunda, Sumatera, Line dance, Hip hop, Kpop, yoga, olah tubuh, hingga menyusun komposisi tari.

MAD School juga memiliki program penunjang seperti workshop dan pementasan. Pementasan bertajuk Metamorfosa hadir setiap semester sebagai ujian siswa-siswinya. Pada skala yang lebih besar dari Metamorfosa, Festival Tinta Tari dihelat sebagai wadah seniman lintas generasi untuk mempresentasikan karya, berdiskusi dengan penontonnya. Tinta Tari juga menjadi salah satu ruang yang mengakomodir pementasan tari kontemporer. Bertemunya penari serta koreografer dengan pengalaman yang berbeda dapat menjadi ajang pembelajaran apresiasi untuk murid MADS sendiri, juga penonton itu sendiri. Festival ini menurut Mila tidak mengkhususkan pada genre tertentu, secara general berbagai penari dapat turut berpartisipasi dalam pementasan tersebut.

\section{Ayu Permata Sari (Ayu Permata Dance Company)}

Lahir dan besar di Kotabumi Lampung. Ayu (25 tahun) mulai belajar beberapa tari dari gurunya Nani Rahayu yang memiliki Sanggar Tari (satu-satunya) di Lampung milik pemerintah sejak kelas 3 SD hingga SMA. Tari yang sempat ia pelajari adalah tari-tarian Lampung, Palembang, beberapa apresiasi tari lain seperti tari Yapong (Kreasi Baru Bagong $\mathrm{K})$, serta olah tubuh. Latihan tersebut dilakukan setiap Jumat dan Minggu selama dua jam. Hampir setiap hari Minggu Ayu pun menari pada acara hajatan baik dalam rangkaian 
upacara adat maupun repertoar tari lepas saat pembukaan acara. Tari tradisi yang ia kuasai antara lain adalah tari Sigeh Pengunten dan tari Bedana, meskipun dalam pementasan tertentu ada permintaan untuk menari tari kreasi sebab dinilai lebih atraktif dan menggunakan perhiasan bagus.

Pementasan Dialog Tari Bandung dengan penata tari Kinanti Sekar Rahina menjadi pengalaman berkesan sebab saat inilah kali pertamanya menari kontemporer. Lalu ia terpilih membantu TA Sekar disandingkan dengan kakak tingkatnya Mila, Sekar, Juni, dan Tita. Ayu merasakan kebanggan pada saat itu namun juga ketakutan bila ia tak berhasil membawakan tariannya. Setiap jadwal latihan, Ayu datang satu jam sebelumnya untuk mengejar hafalan gerak. Ketika proses seleksi 3 TA, penonton dan dosen mengungkapkan bahwa tarian ayu yang paling mirip dengan Sekar (kanonik). Ada kebanggan tersendiri pada saat itu, tetapi lama kelamaan terjadi ambivalensi antara kebanggaan dan jati diri. Bahkan susunan gerak yang Ayu buat dalam karyanya sendiri dibaca oleh penonton kanonik.

Pengalaman pentas Ayu lebih sering bersama Mila Rosinta. Dalam karya-karya S2 Mila, ayu tak pernah absen untuk menjadi penarinya. Ia menjadi anggota MAD grup pada 2012 - 2016. Pada tahun ketiga kuliah di ISI Yogyakarta, Ayu terpilih menjadi salah satu penari AKAR Dance Company yang dipimpin oleh Ana Estelles asal Spanyol bersama Galih Puspita dan Yanti Mei Aryani. Pengalaman baru lagi didapatkan ayu melalui metode eksplorasi yang ditawarkan oleh Ana. Sesungguhnya Ayu termasuk orang yang sangat senang mengikuti workshop tari apapun. Pada tahun 2014 dan 2016 ia menjadi salah satu peserta pilihan workshop penata tari muda Indonesian Dance Festival (IDF). Workshop riset artistik yang juga diselenggarakan oleh IDF pada 2016 pun turut berkontribusi dalam cara ia berkarya kemudian.

Pada Mei 2016, Ayu mendapat tawaran dari event organizer untuk berpentas, tetapi syarat yang diterapkan harus memiliki kelompok. Rekannya pun mengatakan dengan spontan bahwa mereka memiliki kelompok, yaitu Ayu Permata Dance Company (APDC). Lalu atas beban pendidikan dan refleksi, Ayu lantas berpikir untuk serius membangun APDC sebagai ruangnya melakukan eksplorasi atau eksperimen dalam bidang tari.

Program APDC antara lain: (1) Workshop tari dan teknik tari kontemporer yang pernah ia peroleh ke beberapa daerah, yaitu Yogyakarta, Kediri, Bandung, Lampung. Pelaksanan workshop ini menjawab kegelisahan temantemannya yang mengeluh di kota kecil jarang dihelat workshop serupa. Materi workshop dari materi yang pernah didapatkan Ayu. Workshop ini dilakukan empat kali dalam satu tahun; (2) Pementasan karya. Berawal dari keinginan Ayu untuk membuat karya yang ideal disertai dengan data riset. Tema ini lahir berawal dari keinginan untuk mengangkat tentang kehamilan terkait dengan pengajuan hibah cipta perempuan kelola, tetapi gagal mendapatkan dukungan Kelola; (3) Ayu juga membuka kelas olah tubuh seminggu dua kali bagi siapapun yang ingin belajar.

\section{Kawung Art Culture}

Kawung Art Culture merupakan komunitas lahir dari Program Mahasiswa Wirausaha. Awalnya memiliki ketertarikan dalam edukasi seni pada anak-anak yang berdiri pada 2014. Organisasi ini bertindak sebagai organisasi non-profit dalam menjalankan programnya. Pembiayaan program dilakukan dengan menyisihkan pendapatan anggota. Beberapa anggotanya penari (minat kajian dan penciptaan), maka Kawung juga memproduksi beberapa tarian yang berpijak dari seni budaya Yogyakarta maupun Surakarta. Kawung cenderung berbeda dengan yang lain sebab Kawung tidak memiliki seseorang yang dianggap sebagai patron dalam kelompok tersebut. Orang-orang yang berada dalam Kawung dibebaskan untuk berkarya, sehingga besar peluang bahwa karya yang dikerjakan oleh Kawung dihasilkan oleh orang yang berbeda dengan karya yang lain atau bahkan bersifat kolaborasi.

Pada Maret 2017 Kawung mendapatkan hibah ruang kreatif yang diselenggarakan oleh 
Djarum Foundation. Karya berjudul Pat(h)tern hadir terinspirasi dari pengalaman membatik sebagai laku meditatif yang dituangkan dalam bentuk tari kontemporer dipadu dengan video mapping. Beberapa program Kawung yang tercatat hingga saat ini seperti: Ruang Bincang Seni, Kawung Newsletter, Donor Seni, dan program pertukaran budaya dengan Thailand.

\section{Personal \\ I Putu Bagus Bang Sada Graha Saputra}

Lahir dan tumbuh di Bali, I Putu Bagus Bang Sada Graha Saputra (24 tahun) atau lebih akrab dikenal dengan nama Gusbang, telah mengenal tari dari kecil. Ia tumbuh di lingkungan seniman, ayah dan ibunya penari Bali, sedang kakeknya adalah seniman pembuat topeng. Gusbang belajar di Sanggar Lokananta yang tak jauh dari rumahnya semenjak duduk di sekolah dasar hingga menengah pertama. Sang ayah tidak mau mengajarkan menari, Gusbang kecil dibebaskan untuk belajar dengan orang lain. Masa sekolah menengah atas, ia jarang menari lagi. Masuk di Institut Seni Indonesia Yogyakarta setelah lulus SMA adalah saran ayahnya, setelah ia tidak diterima di universitas lain di Yogyakarta. Hal ini menunjukkan bahwa sesungguhnya melanjutkan pendidikan di bidang tari bukanlah tujuan awal Gusbang.

Tahun pertama mengenyam pendidikan di ISI Yogyakarta, Gusbang masih kerap membawakan tari Bali dan menggeluti taritari tradisi. Ia mengenal tari kontemporer dari kakak tingkatnya, Ari Ersandi pada semester 3. Ketika itu Gusbang menjadi penari dalam karya Ari yang berjudul Pintu, dipentaskan di Surakarta. Proses selanjutnya masih dengan dalam karya Ari, Dancember. Gusbang semakin dalam menempa diri dengan tari kontemporer. Ia menemukan kebaruan, keasyikan, maupun kesenangan lain. Pengalaman ketubuhan lain dirasakannya dengan mengolah kemungkinan bentuk lain yang dapat dilakukan oleh tubuh. Selanjutnya intensitas berproses dan berdiskusi bersama Ari Ersandi pun meningkat.

Beberapa ruang aktualisasi diri diikuti, seperti PACo dan Delapan Studio. Bersama kawan-kawan PACo Gusbang memperkaya pengalaman ketubuhannya. Delapan Studio yang digawangi oleh Ari Ersandi berkontribusi pada pemikiran, eksplorasi gerak, dan mengkritisinya. Ia pun dipercaya memimpin Delapan studio pada 2016-2017 ketika Ari mulai mengajar di ISBI Kalimantan. Selesai studi sarjananya, Gusbang melanjutkan ke jenjang magister penciptaan tari di ISI Yogyakarta. Pergulatan dengan tari kontemporer semakin ia dalami. Baginya, kontemporer selain menawarkan kebebasan juga memberikan kesempatan baginya untuk mengkritisi sesuatu melalui karya tari.

Gusbang merupakan sosok penari dan koreografer. Ia mengaku memisahkan bingkai tradisi dan kontemporer ketika ia menari. Ketika membawakan tari tradisi, ketepatan gerak serta aturan (pakem) yang berlaku dipatuhi. Sedangkan dalam tari kontemporer ia merancang gagasan, mengkritisi, dan mempertanyakan hingga mewujud dalam karya tari. Ia memiliki kesadaran penuh bahwa sebebas apapun gerak yang diupayakan gestur Bali selalu melekat entah disadari maupun tidak.

Gusbang menampilkan karya berjudul wayang Tapel pada JIPA 2016. Ia menari tunggal dengan dua karakter topeng yang berbeda. Karya ini merupakan pementasan kedua, pementaasan pertama dihelat di Bali dalam format duet. Karya ini terinspirasi dari kehidupan masa kecil Gusbang yang berada di lingkungan kerja kakeknya, seniman Bali yang membuat topeng dan patung. Lantas ia mengkorelasikannya dengan perilaku manusia. Ia menilai perilaku orang merupakan citra dari apa yang ingin dilihat orang lain terhadapnya. Citra ini lah yang dianggap sebagai topeng. Dalam akhir tarinya Gusbang melepas topengnya, hal ini menandakan bahwa manusia perlu merefleksikan serta melihat kembali citra tersebut untuk memahami dirinya sendiri. Idiom gerak Bali tidak terlihat kental meskipun topeng yang digunakan adalah topeng Bali. Meski demikian, gesturBali Gusbang tidak dapat ditutupi. Meskipun bukan kali pertama penampilan, karya ini tidak sama persis, Gusbang biasa memegang 
struktur tarinya saja sedang detail geraknya merupakan improvisasi.

\section{Galih Puspita Karti}

Terbiasa berinteraksi dengan kesenian sejak kecil, Galih (25 tahun) tekun belajar menari. Ibunya seorang guru tari dan ayahnya seorang dalang membangun sanggar tari di rumahnya Ngasem, Timbulharjo, Sewon, Bantul bernama Puspa Rinonce. Sebelum masuk sekolah taman kanak-kanak ia belajar menari kreasi baru dan klasik gaya Yogyakarta, hingga menjutkan ke jenjang sarjana dan magister di jurusan tari ISI Yogyakarta. Belajar tari tradisi bagi Galih merupakan upaya untuk menuangkan perasaan sebagaimana yang dimaui tariannya, mematuhi pakem/aturan yang berlaku, sembari belajar aktualisasi nilai Jawa.

Galih yang mengakrabi tari tradisi mulai menjajaki tari kontemporer di tahun ke dua masa kuliahnya. Latihan teknik tari dilakukan bersama seniornya, Diantori. Beberapa nomor pementasan karya tari yang berbeda dengan tradisi tubuhnya ia jalani bersama kelompok yang dibangun bersama Diantori dan Akar Dance Company (Anna Estelles). Pengalaman ini mengkayakan perbendaharaan gerak tubuhnya.

Karya-karya Galih tak pernah terlepas dari budaya Jawa, khususnya Yogyakarta. Ia mengaku bahwa ide yang muncul selalu dekat dengan dirinya dan sesuai ketertarikannya. Seni kontemporer bagi dia mengajak penonton untuk berfikir sehingga hanya dapat ditonton oleh kalangan terbatas. Bagi senimannya, kontemporer mengakomodir ide-ide yang tidak dapat dikemas dalam ketaatan pakem tradisional.

Galih selama ini tampil dengan membawa dirinya secara personal. Ketika beberapa kali pentas bersama penari ia menggunakan kelompok Galih Puspita Dance Project. Ia mengaku kelompok ini belum diolah secara serius olehnya, sebab ia ingin beristirahat sejenak pasca menyusun tugas akhir untuk memenuhi tugas di jenjang magisternya. Di sisi lain, Galih pun berkeinginan berbagi metode penciptaan karya tari dengan orang lain. Titik utama Galih dalam berkarya adalah eksplorasi baik gagasan maupun gerak tari dengan sitespesific. Ia belajar bersama Hendro Martono mengenai ziarah ragawi dan laku-telu bersama Miroto.

\section{Membaca Ruang Negosiasi}

Kentalnya iklim tradisi dan kampanye pemerintah atas program preservasi tradisi di Yogyakarta menjadi tantangan tersendiri bagi kebebasan ruang kreatif. Bagi Shils, tradisi adalah sesuatu yang telah diturunkan paling sedikit tiga generasi dan tidak diketahui siapa penciptanya (1981:15). Hal ini menjadi dasar pemikiran alasan tradisi menjadi milik masyarakat penyangganya. Serupa dengan Kayam bahwa kerja tari tradisi bagi generasi pewarisnya adalah mengimitasi, memberi ruang bagi masa lalu untuk tetap hadir di masa ini. Tradisi tampak seperti atap yang dapat menghadirkan kemungkinan untuk sekedar mengikuti atau merespon lebih jauh. Beberapa gelintir orang dari generasi ini melakukan respon atas tradisi yang diterimanya dari generasi terdahulu dan lingkungan dari tempatnya bernaung. Menurut Sal Murgiyanto, perkembangan seni tradisi diartikan hanya sebagai preservasi dengan anggapan keramat yang pantang dijamah. Perkembangan dapat dilakukan tidak lewat inovasi, melainkan interpretasi (Murgiyanto, 2004:68). Sebagaimana yang kekal adalah perubahan, konsep kontemporer lekat dengan persoalan masa, kapan tari itu muncul dan tumbuh. Terdapat perbedaan yang terjadi dalam setiap masa dan wilayah kemunculan tari tersebut. Seni pertunjukan Indonesia menurut Umar Kayam adalah sosok seni pertunjukan yang sangat lentur dan bersifat cair karena lingkungan masyarakatnya yang selalu berubah dalam kondisi yang juga berubah (Kayam, 2000). Perkembangan jaman atau berkembangnya era globalisasi di mana ruang dan waktu tidak lagi menjadi pembatas dan kendala, teknologi komunikasi dan informasi yang semakin terbuka mendorong seni untuk bergelut dengan eksistensinya.

Dalam kasus JDC serta beberapa kelompok dan penari yang telah disebutkan, 
kreativitas menjadi cara negosiasi dengan tradisi. Negosiasi identitas menghubungkan nilai kultural dengan konsepsi individu (TingToomey, 1999:26). Ting-Toomey menjelaskan lebih lanjut bahwa refleksi dari konsepsi individu dilihat sebagai mekanisme komunikasi interkultural. Identitas dilihat sebagai sebuah citra diri yang konstruktif, dialami, dan dikomunikasikan oleh individu melalui kebudayaan dan situasi interaksi tertentu. Konsep tersebut sejalan dengan bagaimana masing-masing anggota JDC melakukan negosiasi dengan kreativitas sebagai alatnya. Negosiasi terjadi dengan bagaimana masingmasing koreografer menempatkan identitasnya sebagai individu dengan tradisi yang telah dipelajari maupun di lingkungan tinggalnya. Secara eksternal, individu koreografer dan penari juga melakukan negosiasi dengan kultur Yogyakarta, tempat karya dipentaskan. Kwan dalam penelitiannya membagi tari kontemporer dalam tiga kategori yakni Contemporary Concert Dance, Contemporary Commercial Dance, dan Contemporary World Dance. Negosiasi dengan kultur lokal dalam praktik tarinya bagi Kwan termasuk dalam kategori ketiga guna mengkritisi westernisasi estetika kontemporer Barat.

Unsur kebebasan termasuk dalam kreativitas untuk mengolah bentuk, corak, maupun semangat yang dapat diwarisi oleh jaman. Tindakan kreatif seseorang muncul dari interaksiindividu denganlingkungan hidupnya (Gruzka and Tang, 2017:59). Kreativitas yang berpegang pada pemahaman mendalam atas nilai-nilai tradisi akan mengkayakan dan mendekatkan nilai tersebut pada masyarakat. Proses kreatif seniman dalam bernegosiasi dengan tradisi, hal ini dibaca oleh peneliti dalam tiga jenis: Pertama, Ide dan Bentuk Garap Mengadopsi Unsur Tradisi. Beberapa seniman memiliki ide yang berpijak dari tradisi seperti cerita ramayana, mahabarata, panji, mitos lokal, dan lain sebagainya. Ide tersebut kemudian diolah dan diwujudkan ke dalam bentuk karya tari baru. Beberapa mengambil bentuk garap dari tari tradisi seperti beksan, Bedhaya, Serimpi, Jathilan, dan lain-lain. Bentuk-bentuk gerak yang ada dalam tarian jenis ini biasanya merupakan pengembangan dari motif gerak pada tari tradisi dengan tetap mematuhi pakem yang ada misalnya menthang, lembeyan, sembah, dan lain-lain. Biasanya tarian semacam ini terdeteksi oleh orang awam sebagai tari tradisi.

Kawung Art Culture membuat karya berjudul Kasetyan (Koreografer: Endang Setyaningsih) dan Sri Lakshita (Koreografer: Ammy Aulia Renata). Kasetyan berkisah mengenai perjalanan hidup Drupadi (istri Yudhistira di cerita Mahabarata). Karya ini dibawakan oleh 4 (empat) orang perempuan, sebagaimana konsep dan struktur tari Serimpi gaya Surakarta. Endang melakukan studi gerak dari salah satu motif gerak yang ada dalam tarian tersebut yakni sembahan laras dan lenggut. Berbeda dengan karya tari Sri Lakshita yang menggunakan struktur maju beksan, beksan, dan mundur beksan seperti halnya dalam tari Serimpi gaya Yogyakarta. Sri Lakshita menceritakan kisah Dewi Sri (dalam mitologi Jawa merupakan dewi padi perlambang kesuburan. Gerak dalam tarian ini berpijak dari motif gerak pada tari gaya Yogyakarta seperti sembahan, kicat, dan sebagainya. Motifmotif tersebut dikembangkan oleh koreogafer namun tetap mentaati aturan tari klasik yang ada. Kedua tarian ini dapat disebut bentuk tari Serimpen, sebab menyerupai Serimpi.

Tarian yang serupa biasanya ditangkap orang awam sebagai tari tradisi sebab unsurunsur pembentuknya masih melekat di permukaan dan dapat teridentifikasi. Beberapa yang lain menggolongkannya pada tari kreasi sebab geraknya merupakan kreasi atas unsur tradisi yang ada. Tak dibicarakan sebagai kontemporer sebab gagasan yang terkait atasnya bukan merupakan penelusuran kritis. Menurut Ramli Ibrahim pada diskusi Senrepita disebutkan bahwa ada pula istilah contemporarytradition, hal ini merujuk ketika tradisi dijadikan sebagai pijakan dengan menambah unsur baru di luar tradisi itu sendiri.

Kedua, Tradisi sebagai Ide Penciptaan Karya. Ide atau gagasan dalam kelompok ini berangkat dari tradisi, namun bentuk garapnya berbeda dengan bentuk tradisi bahkan mengabaikan pakem (aturan) gerak-gerak tradisi. Tampaknya bentuk ini menjadi bentuk 
yang paling banyak dilakukan. Hampir setiap kelompok atau individu yang tergabung dalam JDC memiliki karya tari dalam bentuk ini. Seperti karya Kaganga (APDC), Ngadi Salira (Galih Puspita), Wayang Tapel (Gusbang), Kawung (MAD), Pat(h)tern (Kawung Art Culture).

Pemilihan ini dilihat sebagai bentuk negosiasi pada diri penari maupun ketika telah dihadirkan di ruang publik. Kehadiran ide yang berpijak dari tradisi merupakan sesuatu yang menubuh sebab sebagian besar dari mereka belajar tradisi sejak kecil. Ketika tradisi memuat aturan yang harus ditepati, namun koreografer membutuhkan kebebasan dalam mengekspresikan diri. Bentuk ini muncul sebagai ruang negosiasi yang dilakukan oleh koreografer. Pembelajaran tari tradisi sejak kecil, tidak serta merta membuat mereka memahami tradisinya, bahkan beberapa menyatakan bahwa pemahaman atas tradisi sesungguhnya tidak kuat. Kuat dan tidak tentu dilihat dari sudut pandang para pendahulu yang dianggap sangat memahami nilai-nilai tradisi. Ketidakpercayaan diri ini pula yang terkadang menggiring pada pencarian bentuk baru agar tidak terkungkung dalam pakem, meski tubuh tradisi yang dimiliki oleh masingmasing koreografer tetap melekat.

Ketiga, Isu Personal. Tari selain menjadi salah satu wujud ekspresi, juga merupakan sarana komunikasi nonverbal. Koreografer dapat mengekspresikan apa yang dirasakan melalui kerja kreatif. Dalam mengungkapkan diri dan isu sosial sesungguhnya koreografer pun dapat menggunakan idiom tradisi, namun di sisi lain tradisi terkadang dianggap sebagai pembatas sehingga dapat dikritisi. Pada pembahasan ini peneliti melihat karya tari yang tidak mengambil idiom tari tradisi di dalam karyanya. Fokus dilihat pada ekspresi pengalaman pribadi dan sosialnya.

Women in Hope (MAD) terinspirasi dari pengalaman pribadi koreografer, Mila Rosinta, atas kegagalan proses menuju pelaminan. Ia mencurahkan kekecewaan diri yang telah membina relasi dan berkeinginan untuk sampai pada jenjang pernikahan namun gagal. Gerak Mila terlihat bebas, termasuk juga mengekspresikannya dengan teatrikal melalui mimik wajah. Musik tari menggunakan lagu populer Barat. Berbeda dengan karya Kami Bu-Ta dari Ayu Permata Sari yang ingin mengkomunikasikan kepada khalayak untuk memberhentikan kekerasan seksual. Tariannya bersama Febri menggunakan lima ruang. Ia menunjukkan upaya-upaya yang merujuk pada kekerasan seksual mulai hal yang sederhana seperti siulan sampai dengan pemerkosaan. Ayu menunjukkan pula bahwa kekerasan seksual tersebut dapat terjadi di mana pun, bahkan di rumah oleh anggota keluarga.

Tiga temuan yang merujuk pada proses kreatif koreografer merupakan bentuk dari negosiasi yang ditemukan. Dalam hal ini hanya ada beberapa koreografer yang secara sadar mengklasifikasikan karya mereka pada bingkai tradisi, kreasi, dan kontemporer, sedang beberapa yang lain mengembalikannya kepada penonton untuk menginterpretasi dalam bentuk apa. Simatupang mengungkapan bahwa pendekatan mutakhir dalam kajian tari cenderung pada pengalaman personal, setelah periode sebelumnya terjadi perdebatan mana tari dan bukan tari (2013:55). Terma kontemporer sendiri kemudian dimaknai meluas dan mewakili kebebasan baik gagasan maupun bentuk. Hampir semuanya mengaku membedakan tradisi dan kontemporer ketika menari, meletakkan pada dua sisi yang berlainan. Sugiharto menyampaikan bahwa jargon "kebangkitan/pelestarian budaya" menjadi ambigu karena upaya penciptaan identitas yang solid dan 'strategi pembedaan' untuk meliyankan belaka (2019:55). Tradisi pun dapat dimaknai dengan lebih luas yakni pengulangan, bahkan dalam hal ini yang dialami oleh karya tari kontemporer. Saat tubuh seorang pelaku tari mengalami latihan gerak berulang, maka gerak atau tari tersebut merupakan tradisinya.

\section{Penyelenggaraan}

Pementasan tari menjadi media penting dalam mempertemukan karya tari dengan penontonnya. Sebuah presentasi atas proses yang telah dijalani kemudian bertemu dengan 'mata' lain untuk berbagi rasa. Dalam hal ini 
penyelenggaraan melihat beberapa aspek yang menjadi pertimbangan terkait negosiasinya dengan iklim budaya yang mengelilingi. Pihak penyelenggara merupakan salah satu penopang ekosistem tari yang berkontribusi dalam sebuah produksi pertunjukan (Menear, 1989:7). JDC sebagai sebuah ruang yang mempertemukan berbagai kelompok tari. Kelompok-kelompok ini dalam beberapa kesempatan juga memproduksi ruang mereka sendiri untuk bertemu dengan penontonnya. Pada kasus ini ada 3 (tiga) meliputi: Pertama, Etika ruang publik. Tari-tari kontemporer lebih dikenal oleh masyarakat sebagai sesuatu yang aneh, impresi tersebut dapat menjadi peluang penonton untuk mengulik lebih dalam atau melaluinya. Tidak jarang beberapa orang mengatakan bahwa busana/kostum yang dikenakan terlihat minimal dan seadanya. Dalam hal ini beberapa koreografer ingin fokus terhadap tubuh tarinya pada memiliki alasan konseptual yang dapat dipertanggungjawabkan secara ilmiah. Kebebasan ini salah satunya dengan memperhatikan etika di ruang publik. Seperti pada karya Gusbang yang berjudul wayang Tapel. Pada pertunjukannya, ia hanya mengenakan celana seperti yang dipakai oleh pegulat. Pementasan dengan pakaian minimalis bahkan nyaris telanjang, biasanya ditampilkan di ruang tertutup. Ketika tampil dalan acara JISP di sepanjang jalan Malioboro misalnya, seniman menyadari ruang tersebut berada di tengah publik umum sehingga busana yang dipilih memperhatikan bagian tubuh secara umum biasa tertutup.

Kedua, Pendanaan biasanya dilakukan oleh kelompok itu sendiri atau mengupayakan sponsorship. Lebih banyak yang mengupayakan secara mandiri, dari saku sendiriatau menggalang dana melaluipenjualan merchandise. Menurut pengakuan mereka, mengharapkan dukungan dari pemerintah tidaklah mudah. Yogyakarta memiliki dana keistimewaan yang digelontorkan oleh pemerintah pusat dalam jumlah yang tak sedikit, salah satunya untuk kegiatan seni dan budaya. Bambang Paningron mengatakan bahwa dana keistimewaan memiliki orientasi pada pendidikan, pembinaan, dan pengembangan seni budaya. Asa yang lebih ditekankan terdapat pada konservasi tradisi baik klasik maupun kerakyatan. Tari kontemporer tentu tidak terlihat dalam peta tersebut, maka yang dilakukan Paningron selama ini ditujukan untuk meningkatkan wisatawan sehingga ia meminta dukungan dari dinas Pariwisata. Ia menilai dalam hal ini Dinas Pariwisata lebih lunak, sebab mereka lebih melihat pada efeknya bagi pariwisata. Pada awal tahun 2017 menjadi momentum pertama dana keistimewaan mengusung program berbasis kontemporer bertajuk Lemah Lampah. Meskipun hasil pementasan kurang maksimal dan dilihat siapa yang dapat mengaksesnya. Persoalan ini menarik bila kemudian dapat diteliti lebih lanjut.

Peneliti melihat, dukungan oleh pemerintah sebenarnya telah diwujudkan dalam bangunan Taman Budaya Yogyakarta yang dapat diakses oleh seniman secara terbuka. Pemerintah juga memungkinkan untuk dapat menekan dana penyewaan dengan catatan tidak memungut biaya dari penonton. Akan tetapi besaran biaya yang harus ditanggung angkanya masih dinilai besar, terlebih bagi komunitas non-profit, meski fasilitas yang disediakan cukup lengkap dan murah bila dilihat dari nilai investasi barang. Ruangruang alternatif pun marak, di satu sisi memicu kreativitas agar tidak tergantung pada gedung pertunjukan, di sisi sebaliknya juga menekan biaya.

Ketiga, Berbagi bahwa Pendanaan yang minimal, mendorong kerjasama antar kelompok dapat dilakuan dengan berbagi atas apa yang dimiliki. Tampak pada JIPA 2016 pembagian kerja kepanitiaan pun saling silang, seperti publikasi, dokumentasi, notulensi, konsumsi, dan sebagainya. Acara itu pun menjadi ruang presentasi dan diskusi bagi beberapa koreografer yang tengah berproses menyusun karya tari. Koreografer membutuhkan ruang untuk presentasi karya, penonton pun membutuhkan apresiasi. Ruangruang kecil yang dihelat oleh masing-masing kelompok menjadi penting pergerakannya. Dukungan satu sama lain pun terlihat, seperti 'iuran' dalam bentuk apa yang dimiliki, apakah 
itu ruang, tenaga, atau peralatan. Menurut Brandon, dukungan yang menjadikan seni pertunjukan dapat berkembang di masyarakat menjadikan adanya 'keterikatan sosial' yang kuat yang dapat menopang eksistensi grupgrup pertunjukan di Asia Tenggara.

Pendukung yang dimaksud adalah selain para seniman yang tergabung dalam sebuah rombongan, ada juga dukungan yang tidak kalah penting adalah (1) dukungan pemerintah; (2) dukungan komersial; dan (3) dukungan komunal (Brandon, 20013). Kesenian sebagai salah satu bentuk kreativitas budaya masyarakat baik motif maupun bentuknya mempunyai kaitan erat dengan aspek kebudayaan manusia yang lain seperti bahasa, ekonomi, dan sistem tatanan masyarakat di mana kesenian itu tumbuh hidup dan berkembang.

\section{SIMPULAN}

JDC merupakan forum sukarela yang terbentuk dari berbagai komunitas dan orangorang yang ingin membangun ekosistem tari di Yogyakarta. Berjejaring diperlukan untuk membangun komunikasi antarpelaku sehingga masing-masing seniman dapat bertukar informasi untuk pengembangan potensi individu maupun kelompok. Komunikasi antarseniman memperkuat kelompok itu sendiri serta membuka jejaring dengan pihak luar untuk memperoleh berbagai kesempatan pengembanan.

Kreativitas menjadi cara bernegosiasi anggota JDC. Anggota JDC melakukan interpretasi atas tradisi maupun kultur secara kreatif melalui bentuk, corak, maupun ide dalam penciptaan koreografi. Aktualisasi identitas personal diwujudkan dalam karya tari dengan 3 (tiga) cara yaitu penggunaan idiom tradisi dalam bentuk dan gagasan, gagasan dengan interpretasi gerak bebas, dan pembacaan kultur dari pengalaman personal. Cara ini mampu mengakomodir komunikasi yang terjadi melalui karya dengan kultur di sekelilingnya.

\section{DAFTAR PUSTAKA}

Becker, Howard S. (2008). Art Worlds. Berkeley, Los Angeles, London: University of California Press.

Brandon, James R. (2003). Jejak-Jejak Seni Pertunjukan di Asia Tenggara. Terj. R.M. Soedarsono. Bandung: P4ST UPI.

Bremser, Martha. (1999). Fifty Contemporary Choreographers. London and New York: Routledge.

Chattarjea, Ananya. (2013). “On the Value of Mistranslation and Contaminations: The Category of 'Contemporary Choreography' in Asian Dance". Congress on Research in Dance. DOI: 10.1017/S0149767712000320.

Chilvers, Ian and John Glaves-Smith. (2009). A Dictionary of Modern and Contemporary Art. Second Edition. United Kingdom: Oxford University Press.

Gruzka, Aleksandra and Min Tang. (2017). "The 4P's Creativity Model and its Application in Different Fields". Dalam Min Tang and Cristian H. Werner (ed). Handbook of the Management of Creativity and Innovation: Theory and Practice. Singapore: World Scientific.

Hadi, Sumandiyo. (2001). Pasang Surut Tari Klasik Gaya Yogyakarta PembentukanPerkembangan-Mobilitas. Yogyakarta: Lembaga Penelitian Institut Seni Indonesia Yogyakarta.

http:/ / www.dancemagazine.com/modern_ vs_contemporary-2306900829.html diakses pada Minggu, 23 April 2017 pukul 11.32

Kayam, Umar. (2000). “Seni Pertunjukan Kita" dalam Global Lokal Jurnal Seni Pertunjukan Indonesia. Bandung: MSPI.

Kwan, San San. (2017). "When is Contemporary Dance?". Dance 
Research Journal, Volume 49, number 3, December 2017. Pp 38-52.

Menear, Pauline and Terry Hawkins. (1989). Stage Management and Theatre Administration. New York: Schirmer Books.

Murgiyanto, Sal. (1991). Moving Between Unity and Diversity: Four Indonesian Choreographers. A dissertation submitted to the faculty of the Department of Performance Studies in candidacy for the degree of doctor of philosophy graduate school of Art and Sciences New York University.

(2004). Tradisi dan Inovasi Beberapa Masalah Tari di Indonesia. Jakarta: Wedatama Widya Sastra.

. (2017). Kritik Pertunjukan dan Pengalaman Keindahan. Yogyakarta: Pengkajian Seni Pertunjukan dan Seni Rupa UGM dan Komunitas Senrepita.

Raditya, Michael HB. (2015). “Mencermati Kontemporer dan Memahami Seninya" dalam Prosiding Seminar Nasional Pendidikan Seni bertema Kebangkitan Pendidikan Seni di Indonesia Berbasis Budaya Lokal
Menjelang Era Masyarakat Ekonomi Asia, Surabaya : Fakultas Bahasa dan Seni UNESA.

Shils, Edward. (1981). Tradition. Chicago: The University of Chicago Press.

Simatupang, Lono Lastoro. (2013). Pergelaran Sebuah Mozaik Penelitian Seni-Budaya. Yogyakarta: Jalasutra.

Spradley, James P. (1997). Metode Etnografi. Yogyakarta : PT. Tiara Wacana.

Sugiharto, Bambang. (2019). Kebudayaan dan Kondisi Post-Tradisi: Kajian Filosofis atas Permasalahan Budaya Abad ke21.Yogyakarta: Kanisius.

Supriyanto, Eko. (2015). Perkembangan Gagasan dan Perubahan Bentuk serta Kreativitas Tari Kontemporer Indonesia (Periode 1990-2008) Disertasi Prodi Pengkajian Seni Pertunjukan dan Seni Rupa.

. (2018). Ikat Kait Impulsif Sarira: Gagasan yang Mewujud Era 1990-2008.Yogyakarta: Garudhawaca.

Ting-Toomey, Stella. (1999). Communicating Across Cultures. New York: The Guilford Press. 